\title{
アングルを用いた露出型柱脚の実験的研究 \\ EXPERIMENTAL STUDY ON THE EXPOSED TYPE COLUMN BASE WHICH USES ANGLE AS A JOINT ELEMENT
}

\author{
山.田哲*1, 岡田 健*2, 國岡恭子*3, 薩川恵一*4 \\ Satoshi YAMADA, Ken OKADA, Kyoko KUNIOKA \\ and Keiichi SATSUKAWA
}

\begin{abstract}
In this study, a new type column base, which has high deformation capacity and high repairability, is proposed. Plastic deformation capacity of this column base is brought by the plastic deformation capacity of the angle, which is a joint element. Thus, in this column base, the part which is allowed plastic deformation is limited to the angle, and other part including the anchor bolt is kept in elastic range. The angle can be exchanged easily, when it was damaged. The deformation capacity and the repairability of this column base are verified by axial loading test of angle element and cyclic loading test of column base.
\end{abstract}

Keywords, Exposed type column base, Experimental study, Repairability, Deformation Capacity, Angle 露出型柱脚, 実験的研究, 補修性, 変形能力, アングル

\section{1. 序}

鋼構造骨組における柱脚は、上部構造から基礎構造に力を伝達す る重要な接合部であるだけでなく、地震荷重下において上部構造が 変形しエネルギー吸収する際の要となる。柱脚が備えるべき耐震性 能を考えた場合、梁降伏型やパネル降伏型と言った全体降伏型の骨 組においては骨組全体のエネルギー吸収に古める柱脚のエネルギー 吸収の寄与は僅かであり直接的な影響は少ないが、上部構造に十分 なエネルギー吸収能力を発揮させるための変形追従能力が備わって いることが必要市可欠である”。変形追従能力に優れた柱脚に関す

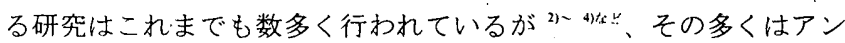
カーボルトあるいはベースプレートの塑性変形により大きな変形に 追従する形式のものである。大地震時に塑性化したアンカーボルト やベースプレートは、重力を支える基礎構造や柱と一体化されてい ることから、損傷後の補修が困難である。

一方、地球環境問題を考えた場合、建物の長寿命化、部材レベル における長寿命化であるリユース、素材レベルでの長寿命化である リサイクルは、構造躯体における環境負荷を低減する上での重要な 方策となる。これら்方策を実施するには、施工性、解体性、補修 性に優れた構法を採用することが望ましい。環境性という観点で構 造要素の一つである柱脚に着目した研究はこれまで行われていな い。

本研究では柱脚の変形能力だけでなく補修性にも着目し、変形追
従能力に優れ、かつ補修性に優れた柱脚を提案する。この柱脚では、 地震時に塑性変形する箅所を交換可能な部品に集約し、損傷後は変 形箇所を交換することで継続使用する。大地震後においても建物を 継続使用できる補修性は、地震国である我が国で建物を長寿命化す るためには必要不可欠であり、環境負荷の低減を考える上で重要な 意味を持つ。また、大地震時における損傷箇所を交換可能な部品に 集約する考え方は、重力を支持する主架構を弾性範囲に留め地震に よる入力エネルギーを取り替え可能なダンパーで吸収させる「損傷 制御構造 」の考え方に基づくものである。本論文では、'変形追従 能力と補修性に優れた露出型柱脚を提案し、要素レベルおよび部材 レベルでの繰り返し載荷実験を通じて、その力学的特性を示す。

\section{2. 本研究で提案する柱脚の概要}

本研究で提案する露出型柱脚を、図-1に示す。この柱脚は、鉄骨 造の柱と基礎構造を、接合金物であるアングルを介してボルト接合 するものである。アングルの耐力を柱や基礎に比べ低くすることで、 大地震時に建物が大きく変形する際、柱と基礎を弾性範囲に留める ことができる。この柱脚はベースプレート降伏型の露出型柱脚の 1 つと見ることもできるが、塑性化部位がボルト接合されたアングル に限定されていることで、柱とベースプレートが溶接で一体化され ている従来の柱脚とは一線を画する高い補修性を有する柱脚となっ ている。

\footnotetext{
${ }^{* 1}$ 東京工業大学建筑物理研究センター 助教授・博上 (工学)

*2 東京工業大学 大学院生・修士 (工学)

*3 元東京工業大学 大学院生・修士 (工学) (現 JR 九州)

*4 元東京工業大学建築物理研究センター 研究員.・博士(工学) (現東京理科大学 助手)
}

\author{
Assoc. Prof., Structural Engineering Research Center, Tokyo Institute of \\ Technology, Dr. Eng. \\ Graduate Student, Tokyo Institute of Technology, M. Eng. \\ Former Graduate Student, Tokyo Institute of Technology, M. Eng.
}

Former Research Fellow, Structural Engineering Research Center, Tokyo Institute of Technology, Dr. Eng. 
大地震後における補修性を確保するために、塑性化部位をアング ルに限定するためには、損傷を受けた場合に補修が困難なアンカー ボルトを弾性範囲に留める必要がある。本研究で提案する柱脚では、 アングルと柱の接合には高力ボルトを使用し、アンカーボルトにも 高強度材料を使用して、アングルが大きく塑性変形するような状況 においてもボルト類は弾性範囲に留める。

アングルに引き抜きカが作用した状況を図-2に模式的に示す。ア ンカーボルトには、アングルに作用する引き抜きカP $P$ と、アングル の先端に生じるてこ反カRの和と釣り合う大きな引き抜き力 $T$ が作 用することから、アングルの降伏耐力に応じた引き抜き力が作用し た場合にも、アンカーボルトが離間しないよう設計する。また、引 き抜き力が作用する際、アングルには図-2に示したようなモーメン トが作用する。曲げモーメントはボルト位置で最大となり、アング ルの曲げ変形に伴いアンカーボルトにも曲げモーメントが加わる。 ボルト位置でアングルが塑性化するような場合にアンカーボルトを 弾性に留めるためには、曲げモーメントにも抵抗できる大きな断面 とするなどの対策が必要である。そこで本研究では、ボルト位置で アングルを曲げ降伏させないための 2 つの方法を採用した。

1 つ目は、図-3に示す板厚の厚い座板を設ける方法 ${ }^{6)}$ である。厚 い座板を設けることで、アングルが曲げ降伏する位置を座板端部と する。そして、ボルト位置に作用する曲げモーメントに対しては、 座板の降伏モーメントをアングルが塑性化した時にボルト位置に作 用するモーメントより大きく設計することで、座板およびアングル を弾性範囲に留め、ボルトに大きな曲げが加わらないようにする。2 つ目は、図-4に示すように、アングルに切り欠きを設ける方法であ る。ヒンジが形成される切り欠き部の耐力が低くなっていることで、 ボルト位置に作用する曲げモーメントは低減される。切り欠きの位 置と大きさは、アングルが塑性化した時にボルト位置に生じる曲げ モーメントが、アングルの降伏モーメントを越えないように設計す る。
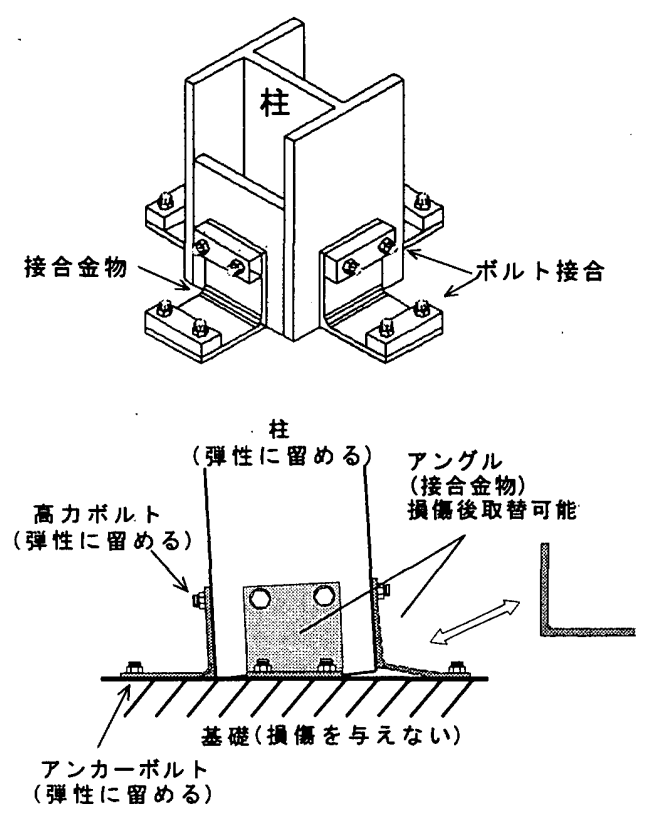

图-1 柱脚の概要

\section{3. アングルの要素実験}

\section{1 実験概要}

本研究で提案する柱脚においては、接合金物であるアングルが変 形要素となっている。軸力と繰り返し曲げを受ける柱脚の履歴举動 は、アングルの弾塑性挙動に基づいたものとなる。柱脚の部材実験 に先立ち、アングルの弾塑性履歴挙動を把握するため、柱脚に組み 込まれた状態を想定したアングルの繰り返し載荷実験を行った。

試験体に用いたアングルは、L-150x150x12(SS400)であり、幅は $130 \mathrm{~mm}$ とした。試験体のパラメーターはアングルの接合方式であ り、座板を用いるタイプ(座板型)と切り欠きを設けるタイプ(切欠型) の 2 体とした。座板型では、板厚 $28 \mathrm{~mm}$ 、幅 $44 \mathrm{~mm}$ の座板(SS400) を使用し、切欠型では、先端から $44 \mathrm{~mm}$ の位置に $\mathrm{r}=8 \mathrm{~mm}$ の切り欠 きを設けた。試験体の断面形状を図-5に、JIS-1A 号試験片による 素材引張試験結果を図-6に示す。アングルの取り付けに用いたボル トはM16F10T の高力ボルトである。

セットアップの概略を図-7に示す。加力には変位制御型万能試験 機を用い、鉛直方向片振幅繰り返し載荷を行った。実験では、試験 体である 2 体のアングルを加力治具を挟んで対称に設置し、加力治 具及び反力治具に高力ボルトで接合した。高力ボルトの締め付けは、 設計用トルク值により管理した。実験における計測項目は、試験機 のロードセル出力である鉛直力と、鉛直変位 $\delta_{v}$ であり、 $\delta_{v}$ で $0.5 \mathrm{~mm}$, $1.0 \mathrm{~mm}, 2.5 \mathrm{~mm}, 5 \mathrm{~mm}, 12.5 \mathrm{~mm}, 25 \mathrm{~mm}$ の片振幅各 1 回の載荷を行っ た。

\section{2 実験結果}

要素実験の結果を、片側のアングルで負担する鉛直力 $P$ と鉛直変 位 $\delta_{v}$ の関係で整理し、図-8 に示す。座板型と切久型のいずれの要素 試験体も、25mm の振幅まで安定した履歴挙動を示した。また、載 荷終了に至るまで、アングルへの亀裂の発生およびボルトの塑性変 形は観察されなかった。25mm の浮き上がり量を柱脚部引張側の浮 き上がり量としてみると、柱の成で $250 \mathrm{~mm}$ に対して柱脚部の回転 角で $1 / 10 、 500 \mathrm{~mm}$ に対して $1 / 20$ に相当する。露出型柱脚の接合金 物としては十分な変形領域に至るまで、安定した履歷挙動を示した と言えよう。
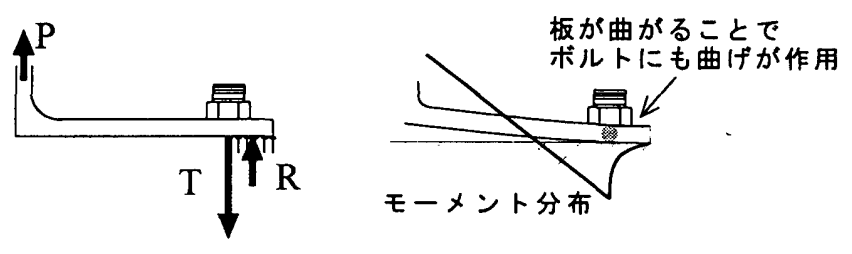

図-2 アンカーボルトに作用するカ

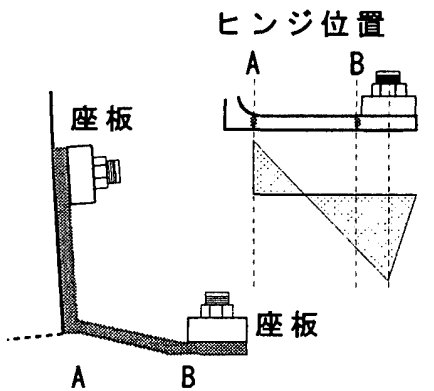

図-3 座板を設ける方法

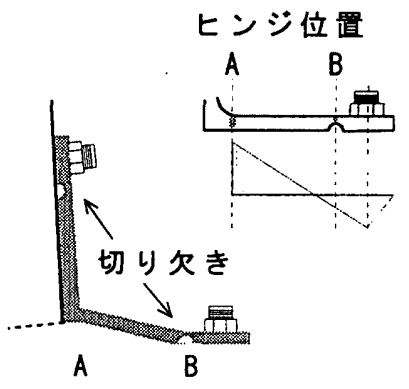

図-4 切り欠きを設ける方法 


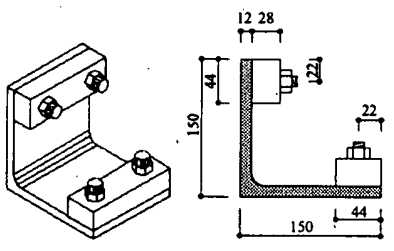

(1) 座板型
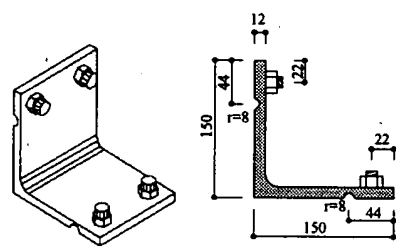

(2)切欠型
図-5 要素実験試験体

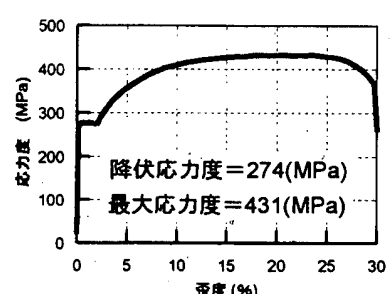

図-6 素材試験結果(要素実験)

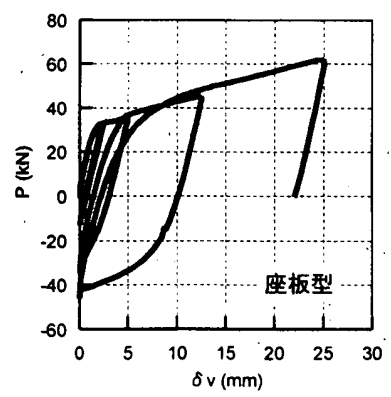

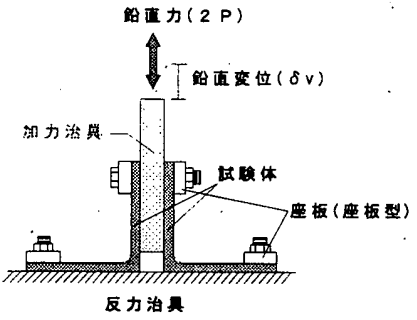

図-7 要素実験セットアップ

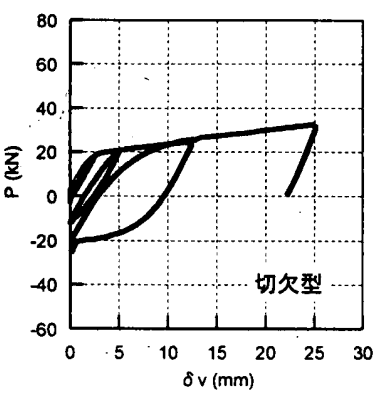

図-8 要素実験結果

\section{3 アングルの履歴挙動の解析}

図-9に示す力学モデルを用いて、アングルの履歴挙動を鉛直力 $P$ と鉛直変位 $\delta_{v}$ の関係において解析する。このモデルでは、鉛直力を 受ける場合に主要変形要素となる横材について、座板型では両端固 定、切欠型では一端固定一端ピンの梁材にモデル化し、変形要素を 固定端に設けた弾塑性ヒンジに集約した。一方、軸力を伝達する以 外は鉛直方向の復元力にはあまり寄与しないと考えられる綖材は、 両端ピンの剛体にモデル化した。アングルが塑性化し、降伏機構を 形成した後の挙動については、変形の大部分が横材の塑性変形に起 因寸ると考えれば、このようなモデル化でも履歴挙動は概ね評価で きると考えられる。ただし弾性範用の挙動については、実際の変形 状態に忘じた剛性とするするため、縌材と横材の間に㓮性を調整す るための弾性バネを挿入し、解析モデルの弾性剛性が撓み角法によ り求めたアングルの弾性剛性の值と一致するよう弾性バネの剛性を 設定した。また、アングルの浮き上がりに伴う横材のモーメントア 一ムの変化については、图-9中に示すように、ヒンジ間を慗ぐ剛体 の回転に伴う変化を考慮することで対応した。モデル化された横材 におけるヒンジの位置については、図-10に示すように、先端側は 座板型では座板端位置に弾塑性ヒンジを設け、切欠型では切り欠き 底位置をピンとした。またフィレット側ではコーナー部の変形を考 慮して、平行部端よりフィレット側に $\mathrm{r} / 3$ 入った位置に弾塑性七
ンジを設けた。

撓み角法による弾性剛性の算定においては、アングルを図-11に 示す線材モデルに置換した。ここで、座板型については、座板で拘 束される端部が完全な固定端とはならないことから、固定度の影響. を反映するために、端部に弾性回転バネ(剛性 $K^{\prime}$ )を挿入したモデル とした。K'の值は実験結果における弾性剛性と比較検討した結果、 座板端部において、座板端部からボルト位置までの区間を単純梁と 仮定したときに、座板端部において曲げを受けた場合に発生する材 端回転角相当の回転角が生じるものとして、

$$
\begin{aligned}
& K^{\prime}=3 E I / L_{w} \\
& \text { ここで、 } L_{w}: \text { ボルト中心位置から座板端までの距離 }
\end{aligned}
$$

とした。一方、切久型については、切り久き位置をピンとしたモデ ルを用いた。

弾塑性ヒンジの履歴挙動については、図-12に示すような、骨格 曲線、弾性除荷部、バウシンガー部の組み合わせで構成されたモデ ルを用いた。このうち、新たに到達した荷重領域における履歴曲線 をつなぎ合わせた骨格曲線は、一方向載荷時にお付る荷重一変形関 係と等価である”ことから、数值積分による面内解析法 "゙ะによる せん断曲げを受ける横材の荷重-変形関係の解析結果に基づきモデ ル化した。座板型については、横材を逆対象曲げを受ける梁材にモ デル化したことから、半スパン分であるスパン $L_{s} / 2$ の単純梁につい て荷重-変形関倸(モーメント-部材角関係)を解析し、解析結果を Tri-Linear 型にモデル化した。骨格曲線のモデルを解析結果と併せ て図-13に示す。このモデルでは、第 1 折点は全塑性モーメント $M_{p . a}$ と全塑性モーメントに対応する弾性変形角 $\theta_{p, a}$ であり、式(2),(3) で与えられる。

$$
\begin{aligned}
& M_{p, a}=\sigma_{y, a} \cdot t_{a}{ }^{2} \cdot B_{a} / 4 \\
& \theta_{p, a}=\left[M_{p, a} \cdot L_{s} /(\sigma \cdot E \cdot I)+.2 M_{p, a} /\left(G \cdot t_{a} \cdot B_{a} \cdot L_{s}\right)\right] \\
& \text { ここで、 } \sigma_{y, a}: \text { アングル材の降伏点 } \\
& t_{a}: \text { アングルの板厚 } \\
& B_{a}: \text { アングルの幅 } \\
& L_{s} \text { :ヒンジ間距離(図-9参照) } \\
& E \text { :弾性倸数 } \\
& I=B_{a} \cdot t_{a}{ }^{3 / I 2} \\
& G: \text { せん断弾性係数 }
\end{aligned}
$$

一方、切欠型では切欠部は完全なピンとなるわけではなく、板厚に 応じて外力に抵抗する。反曲点より切欠側の領域における曲げ変形 は微少であると考えられることから、以下のようにモーメント-部 材角関倸をモデル化した。アングルの板厚を $t_{a}$ 、切欠底の板厚を $t_{n}$ 、 $a=t_{n}^{2} 2\left(t_{a}^{2}+t_{n}{ }^{2}\right)$ とすると、塑性化した状態での横材の反曲点位置はフ ィレット側から $(I-a) \cdot L_{s}$ の位置となる。反曲点からフィレット側の 部分について、一端に曲げを受ける単純梁として荷重-変形関係を 解析する。これを、変形角については切欠側の $a \cdot L_{s}$ の領域が剛域 であるとみなして $1 /(1-a)$ 倍し、モーメントについても横材が伝え るせん断力が切欠位置での曲げ抵抗を考慮した場合と等しくなるよ うl/(l-a)倍したものを、横材を一端固定一端ピンの条件に置換し た場合の荷重-変形関倸とみなし、Tri-Linear 型にモデル化した。骨 
格曲線のモデルを、モーメント、変形角ともにl/(l-a) 倍した解析 結果と併せて、図-12に示す。このモデルにおける第 1 折点である 全塑性モーメント $M_{p, a^{\prime}}$ とそれに対応する弾性変形角 $\theta_{p, a^{\prime}}$ は、式(4),(5) で与えられる。

$$
\begin{aligned}
M_{p, a^{\prime}}= & I /(1-a) \cdot \sigma_{y, a} \cdot t_{a}{ }^{2} \cdot B_{a} / 4 \\
\theta_{p, a^{\prime}}= & M_{p, a} \cdot L_{s} \cdot(1-a) /(3 \cdot E \cdot I) . \\
& +M_{p, a^{\prime}} /\left\{G \cdot t_{a} \cdot B_{a} \cdot L_{s} \cdot(I-a)\right\}
\end{aligned}
$$

降伏後の挙動については、座板型・切欠型のいずれについても、第
1 折点から第 2 折点の区間は弾性剛性の $2 \%$ の剛性とし、第 2 折点 は回転角でl $6 \theta_{p, a}$ (切欠型では $\left.16 \theta_{p, a^{\prime}}\right)$ の点、第 2 折点以降は弾性剛 性の $1 \%$ の剛性とした。また、バウシンガー部については、文献 9) のモデルを用いることとした。

以上のようにモデル化して計算したアングルの履歴举動の解析結 果を、実験結果と比較し図-14に示す。解析結果はバウシンガー効 果による剛性低下を含め、実験結果と良い対応を示している。繰り 返し荷重を受けるアングルの履歴挙動は、图-9に示すカ学モデルを 用いることで予測できることが判った。

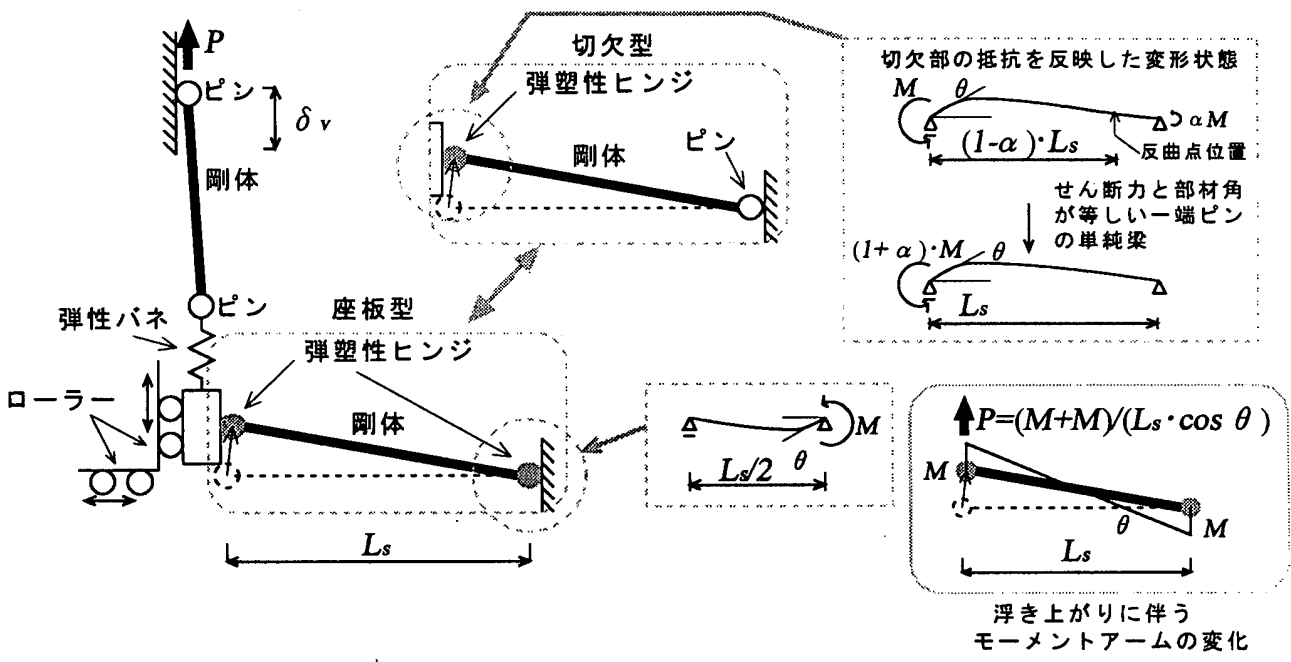

図-9 アングル要素のカ学モデル

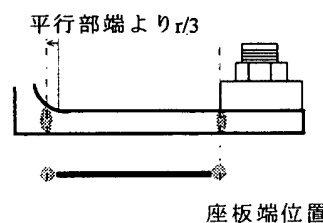

図-10 ヒンジ位置の設定

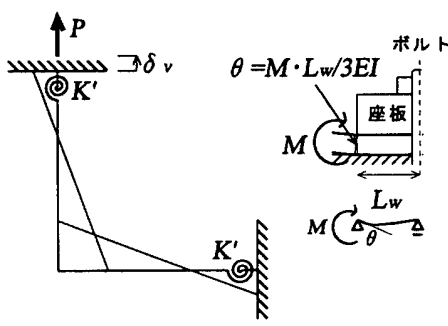

(1)座板型

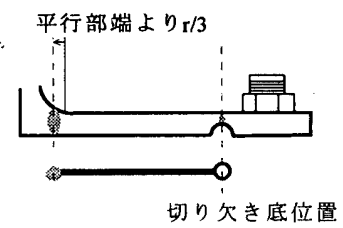

切り久底位置

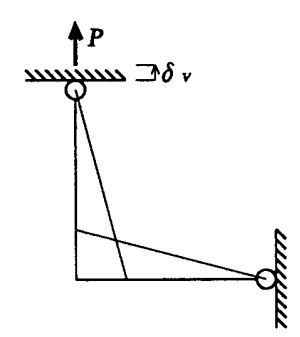

(2)切欠型

図-11 撓み角法による弾性剛性の算定

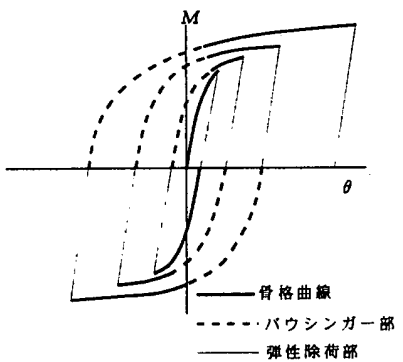

図-12 弾塑性ヒンジにおける履歴挙動の分解
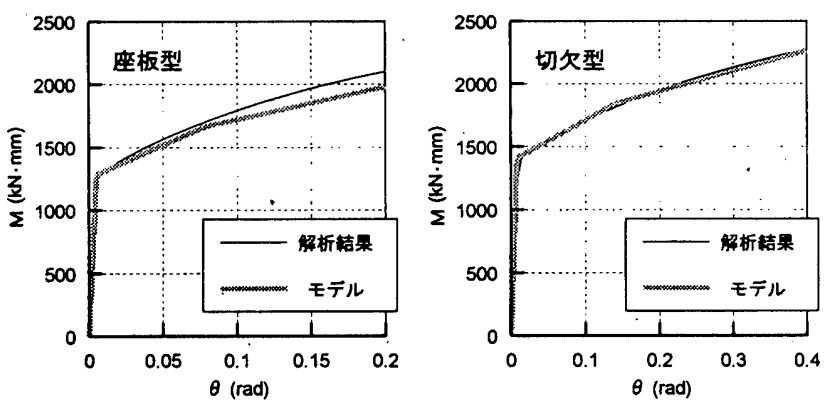

図-13 横材の骨格曲線
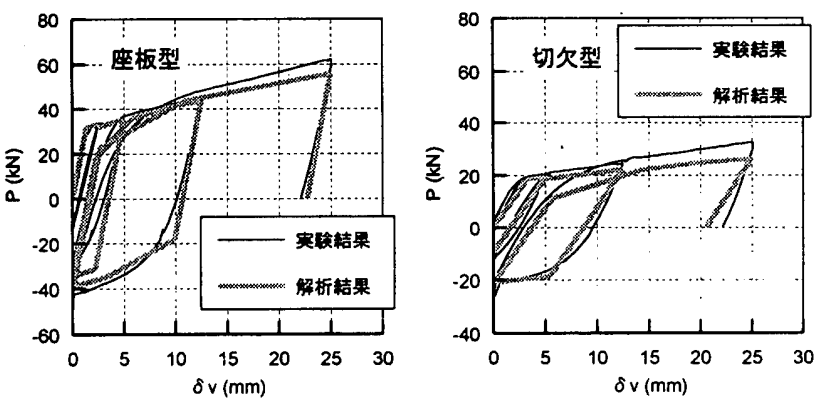

図-14 解析結果と実験結果の比較 


\section{4. 柱脚の部材実験}

\section{1 試験体}

本実験のパラメーターは、柱に作用する軸力と柱脚の接合金物で あるアングルの接合方式である。試験体の一覧を柱の軸力と併せて 表-1に示す。柱に作用する軸力については、圧縮力を正として 0 , $200(\mathrm{kN}), 400(\mathrm{kN}),-100(\mathrm{kN}),-200(\mathrm{kN})$ の一定軸力と、地震時に作用寸 る付加軸力の影響を想定した変動軸力とした。軸力の変動パターン については図-16に示すように設定したが、これらは上部構造が降， 伏機構を形成した後は、柱の軸力はほとんど変動しないことをイメ ージして設定した。一方アングルの接合方式については、要素実験 同様、座板を用いた座板型とアングルに切り欠きを設けた切欠型の 2 種類とした。使用したアングルは L-150x150x12(SS400)で幅は $150 \mathrm{~mm}$ 、座板型で用いた座板(SS400)の板厚、幅はそれぞれ $28 \mathrm{~mm}$ 、 $50 \mathrm{~mm}$ 、切欠型における切り欠き $(\mathrm{r}=8 \mathrm{~mm})$ は、先端から $50 \mathrm{~mm}$ の位 置に設けている。両タイプの詳細を図-16に、JIS-1A 号試験片によ るアシグルの素材引張試験結果を図-17に示す。本研究で提案する 柱脚は、基本的にベースプレート降伏型の柱脚であることから、降 伏線理論により耐力を予測することができる。圧縮軸力が作用した 状態および軸力が作用しない状態での降伏機構は、図-18のように なると考えられる。仮定した降伏機構に対する柱脚の予測降伏耐力 を表-2に示す。柱脚の最大耐力は、歪硬化などの影響により゙これよ り上昇すると考えられることから、弾性範囲に留める柱などの周辺 部材は、柱脚の予測降伏耐力より十分大きくなるように設計する。

また、本研究で扱う柱脚では、アンカーボルトは弾性範囲に留め ることを前提として高強度材料の使用を想定していることから、ボ ルトに生じる引抜力が許容引張り耐力以下となるよう、アングル 1 個あたり 2 本の M24F10T の高力ボルトを使用し、締め付けは設計 用卜ルク值により管理した。柱とアングルの接合においても、アン グルの変形に伴いボルトに曲げモーメントが作用することから、ア ンカーボルト側と同じ接合方式としたうえで、設計用トルク值によ り管理した M24F10T・の高力ボルトを使用した。なお、ボルト径が $24 \mathrm{~mm}$ であるのに対して、縁端距離が $25 \mathrm{~mm}$ と最小縁端距離の規定 を満足していないが、アングルにできる塑性ヒンジ間の距離を大き く取っていることで、アングルが伝えることのできる力が端抜け破

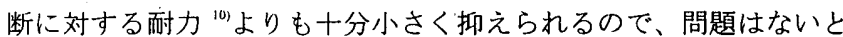
考えた。

\section{2 実験方法}

実験装置の概要を図-19に示す。実験装置は反カフレームに組み 込まれた水平方向・垂直方向の 2 本の油圧式ジャッキ、加力治具を 兼ねた柱、基礎部を模した反力治具、柱の面外方向への変位を抑え る拘束治具そして試験体部分であるアングルを接合金物に用いた柱 脚により構成される。加力治具を兼ねた柱の断面形状は、柱脚に比

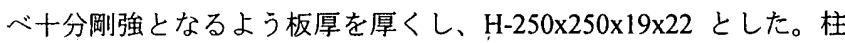
の底面には $22 \mathrm{~mm}$ 厚のベースプレート $(250 \mathrm{mmx} 250 \mathrm{~mm})$ が溶接され ているほか、下端から $250 \mathrm{~mm}$ までが板厚 $22 \mathrm{~mm}$ のカバープレート を溶接した日の字断面となっている。接合金物であるアングルを組 み込んだ柱脚部(試験体部分)の詳細を図-20に示す。基礎部を模し た反力治具についても、柱同様柱脚に比べ十分剛強となっている。

試験体に作用する力については、油圧式ジャッキ先端に取り付け られたロードセルによる荷重の計測值と、加力点近傍に設置した変
位計により計測される加力点の変位および回転角から、柱脚部に作 用する軸力と曲げモーメント ${ }^{B} M$ として算出した。柱脚部の变形に ついては、変位計により柱下端部における回転角を計測し、これを 柱脚部の回転角 $B$ とした。載荷は柱脚部の回転角 $B \theta$ により制御し、 ${ }_{B} \theta= \pm 0.005(\mathrm{rad}) \rightarrow{ }_{B} \theta= \pm 0.01(\mathrm{rad}) \rightarrow{ }_{B} \theta= \pm 0.02(\mathrm{rad}) \rightarrow{ }_{B} \theta= \pm 0.03(\mathrm{rad}) \rightarrow$ ${ }_{B} \theta= \pm 0.04(\mathrm{rad}) \rightarrow \rightarrow_{B} \theta= \pm 0.05(\mathrm{rad})$ の振幅で各 1 回の載荷を行う繰返漸 増変位振幅載荷とした。なお、A_000 と A_M200 以外の 7 体の試 験体については、最大振幅である ${ }^{8} \theta= \pm 0.05(\mathrm{rad})$ の振幅で 2 回載荷 を行った。
表-1 試験体一覧

\begin{tabular}{|c|c|c|}
\hline 场硢体名 & \begin{tabular}{|l|} 
アングル \\
の形式 \\
\end{tabular} & 軸力 $(\mathrm{kN}) * 1$ \\
\hline A_000 & 座板型 & 0 \\
\hline A_200 & 座板型 & 200 \\
\hline A_ 400 & 座板型 & 400 \\
\hline A_M100 & 座板型 & -100 \\
\hline A_M200 & 座板型 & -200 \\
\hline A_V1 & 座板型 & パターン1*2 \\
\hline A_V2 & 座金型 & パターン2*2 \\
\hline B_000 & 切欠型 &.$\quad 0$ \\
\hline B_400 & 切欠型 & 400 \\
\hline
\end{tabular}

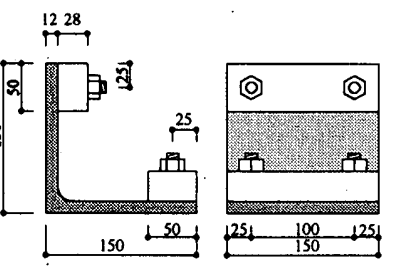

(1) 座板型

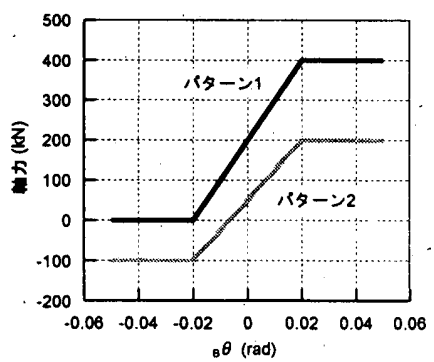

図-15 軸力の変動パターン

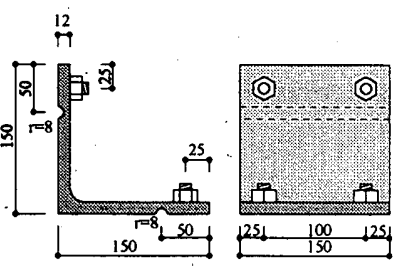

(2) 切欠型

図-16 アングルの形状

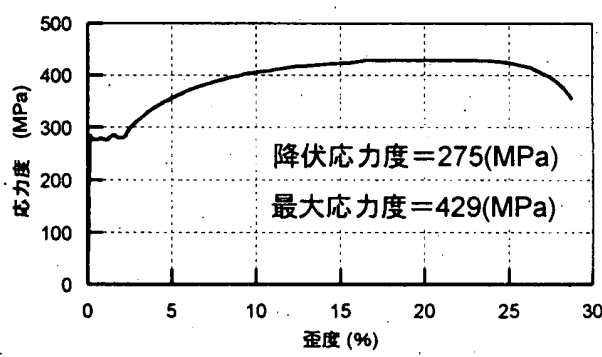

図-17 アングルの素材試験結果 (部材実験)

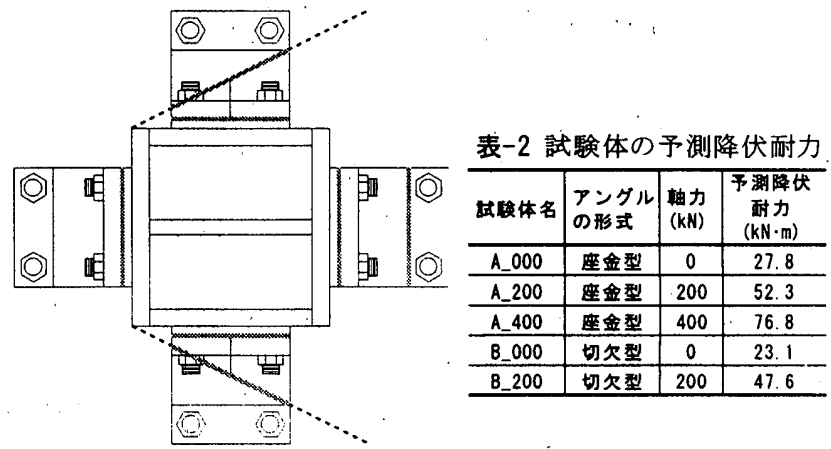

図-18 仮定した降伏機構 


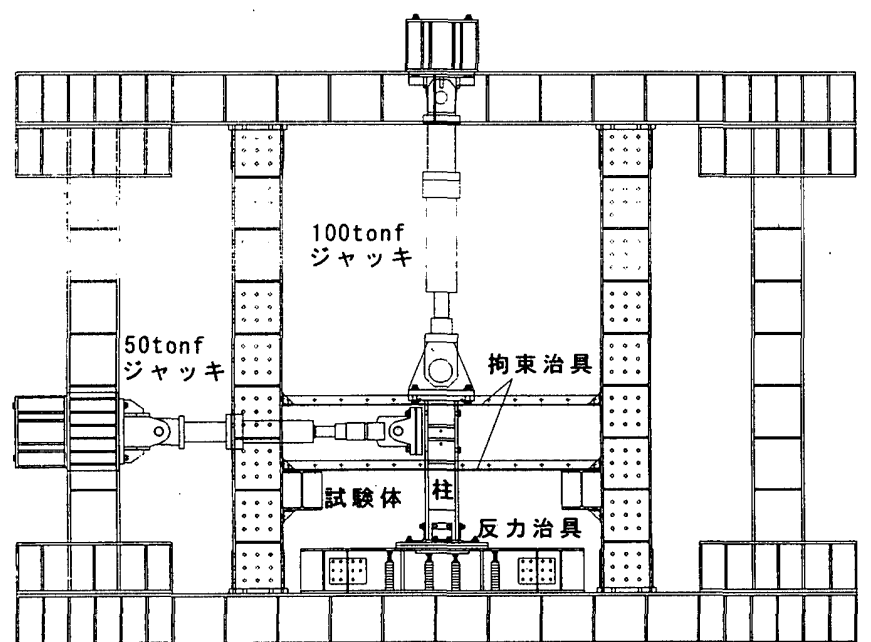

図-19 実験装置

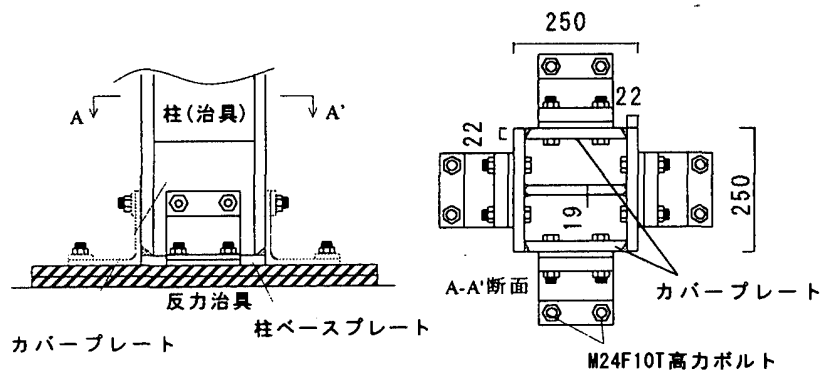

図-20 柱脚部詳細
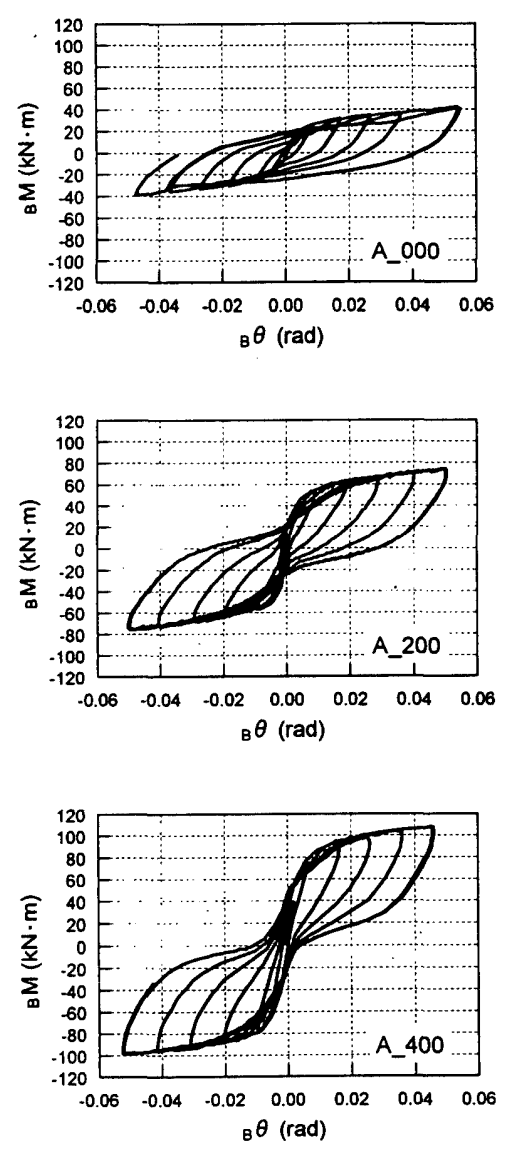

\section{3 実験結果}

各試験体の荷重-変形関係を、柱脚部に生じるモーメント ${ }_{B} M$ と柱 脚部の回転角成の関係で整理し、図-21に示す。全試験体、最大変 位振幅である ${ }^{B} \theta= \pm 0.05(\mathrm{rad})$ に至るまで耐力を亦失することなく安 定した変形能力を発揮した。載荷終了に至るまで、アングルに亀裂 は発生せずボルトも塑性化しなかったことから、部材実験によって アングルを接合金物として用いた露出型柱脚の変形追従能力の高さ が検証できたと言える。

荷重-変形関係であるが、一定の圧縮軸力を作用させた試験体は、 原点付近で軸力による抵抗モーメントを発揮した後前回の除荷点を 指向する安定した履歴曲線を描いた。本研究で提案した柱脚は、基 本的にベースプレート降伏型の露出型柱脚であることから、典型的 なスリップ型の復元力特性となる一般的なアンカーボルト降伏型の 露出型柱脚に比べ、安定した履歴挙動を示したと言える。また、軸 カを 0 とした試験体と一定の引張軸力を作用させた試験体は、紡鏵 型の復元力特性を示した。そして、変動軸力を作用させた試験体は、 圧縮軸力が作用する領域では一定の圧縮軸力を作用させた試験体と 同様の復元力特性を示し、引張軸力が作用する領域では一定の引張 軸力を作用させた試験体と同棣の復元力特性を示した。なお、一定 の圧縮軸力を作用させた試験体および軸力を 0 とした試験体の降伏 耐力は、概ね降伏線理論による予測值と対応した結果となった。

また、全ての試験体において、ボルトが塑性化しなかったことに より載荷終了後のアングルの取り替えは支障無く行えた。本柱脚の 特徵である補修性についても、実験的に検証できた。
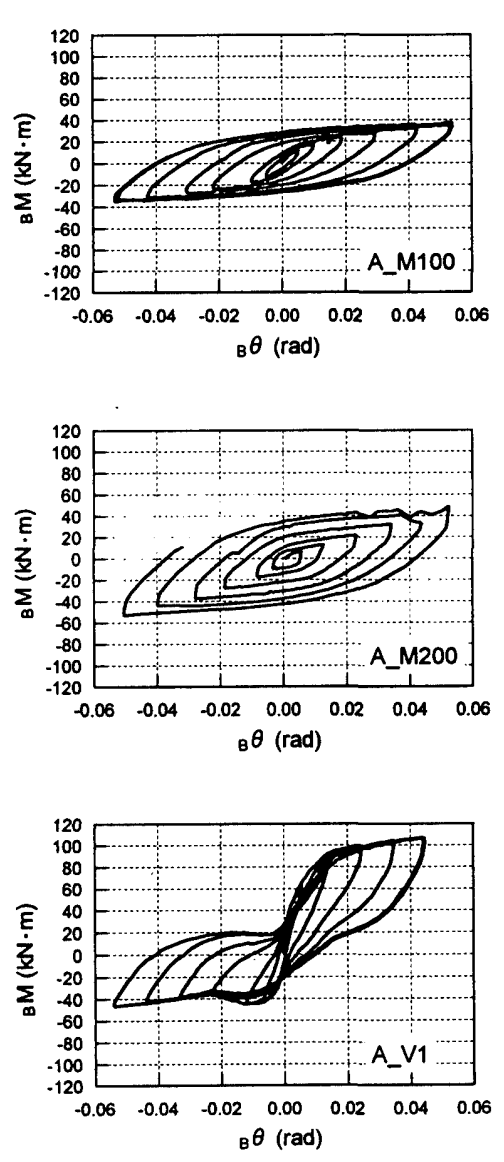

図-21 試験体の荷重-変形関係
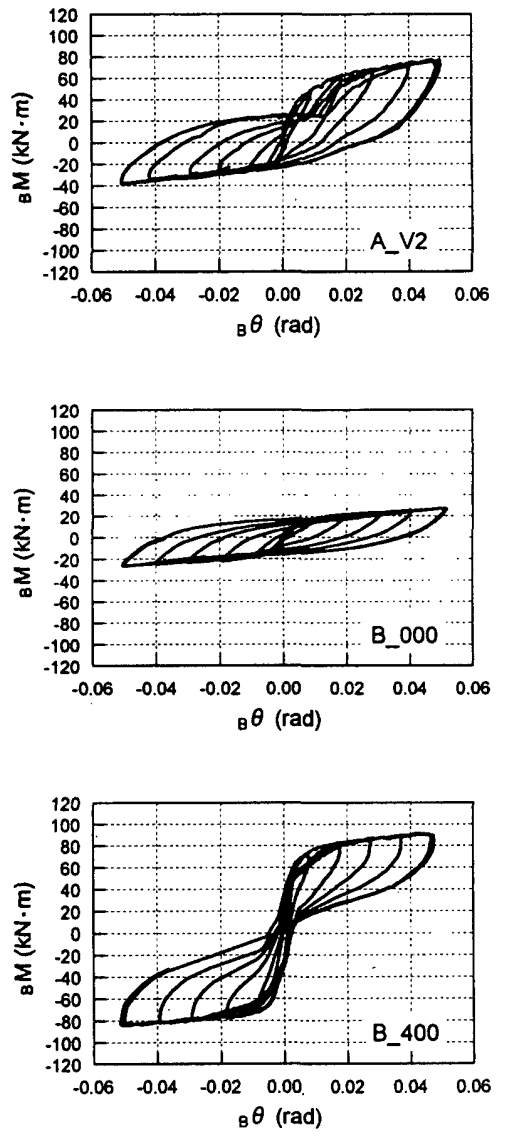


\section{4 柱脚の履歴挙動の解析}

柱脚の履歷挙動を解析するにあたり、柱脚部を図-22に示すよう に、複数のバネでモデル化した。図中、バネS lo およびバネ S ro は 曲げモーメントの作用する側のアングルに対応し、バネ Sli および バネ Sri は側面のアングルに対応する。このうち、曲げモーメント の作用する側のアングルについては、3.3 節で示した方法により鉛 直方向に作用するバネとしてモデル化した。・゙ネの位置は横材にお ける反曲点位置であり、図-22中の $L_{1} は 、$ 柱端より横材の反曲点位 置までの距離である。

一方、側面側のアングルについては、座板型と切欠型のいずれに ついても、図-22中に示すように先端側には斜め方向に降伏線がで き、これとフィレット側の降伏線によって降伏機構が形成される。 斜め方向の降伏線は、変形方向ごとに反転した位置にできるだけで なく、柱脚全体に浮き上がり変形が生じるような場合には、浮ぎ上 がり状態に応じて移動する。本研究では、複雑な挙動を示す側面側 のアングルを平均的に捉えるため、座板型については、幅方向に $1 / 2$ に分割した上で、柱脚全体の浮き上がり変形が生じない場合のヒン ジ間距離の平均值 $L_{s}{ }^{\prime}$ を以て横材の長さヒンジ間距離として、3.3 節 で示した方法による鉛直方向に作用するバネとしてモデル化を行っ た。バネの位置はそれぞれ幅方向に $1 / 2$ に分割したときの重心位置 である。一方、切欠型の側面側のアングルについては、降伏機構が 座板型と等価となることから、弾性剛性の対応においては恣意的で はあるが、座板型のモデルを適用した。
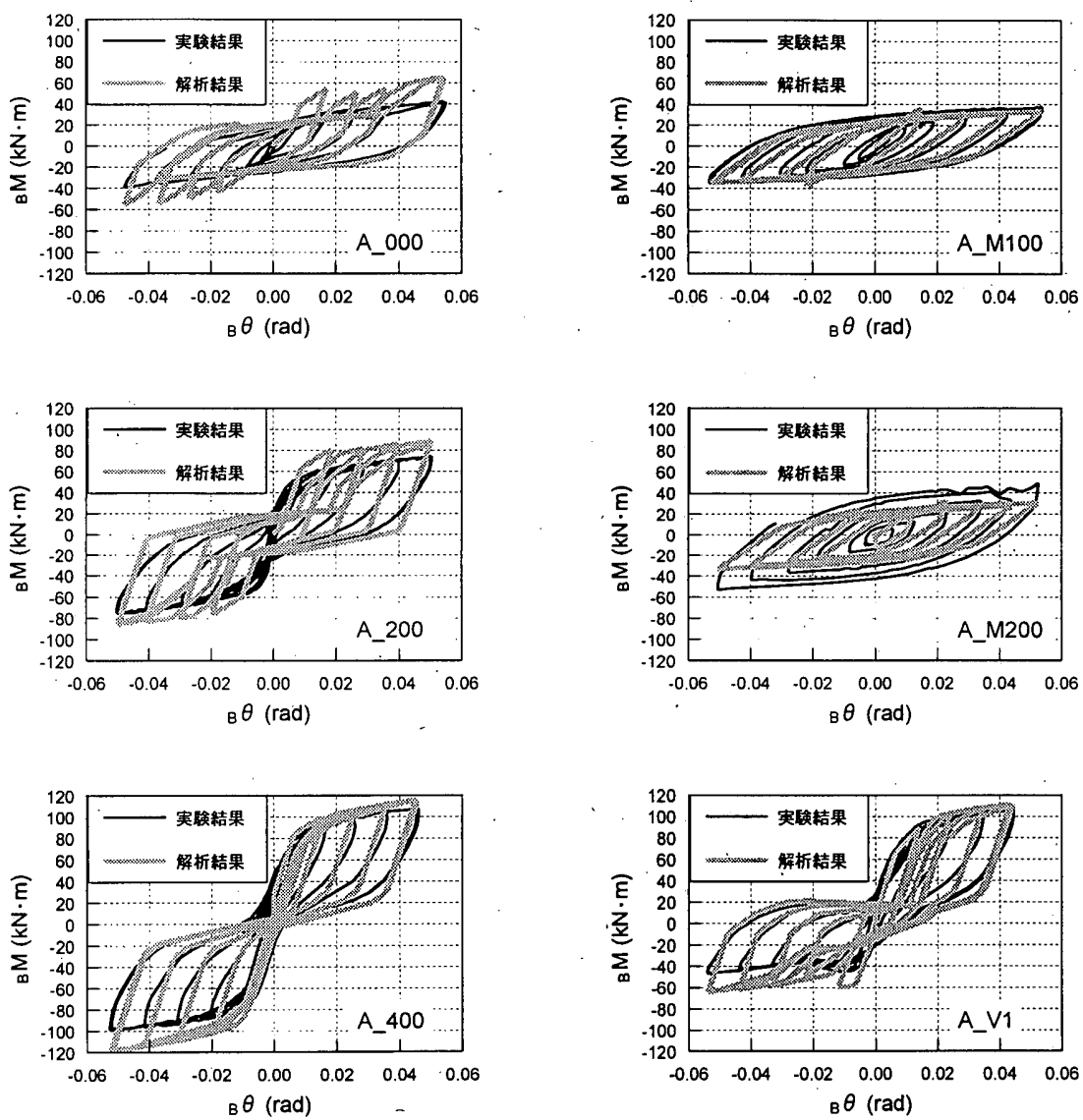

図-23 解析結果と実験結果の比較

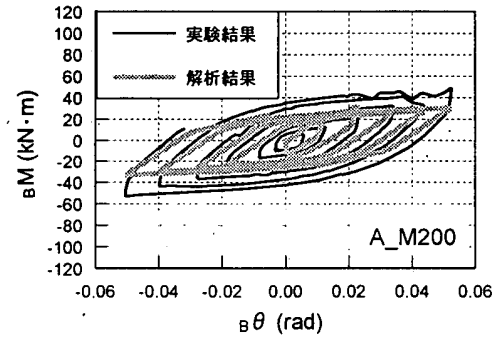

これらアングルをモデル化したバネは、その位置において浮き上 がり変形が生じる際に変形し、柱の左右両端においては、柱端にお ける浮き上がり変形が 0 となると同時に、基礎からの支圧反力C も しくはC $C_{r}$ が作用する。柱脚における力の釣り合いを、図-22中に模

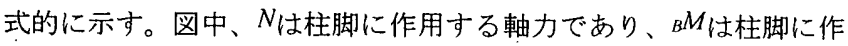

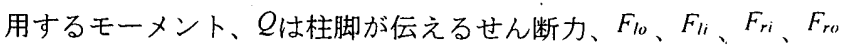
はそれぞれバネ Slo、Sro、Sli、S ri の復元力である。軸方向力の釣り 合いは式(6)で、曲げモーメントの釣り合いは式(7)で表される。

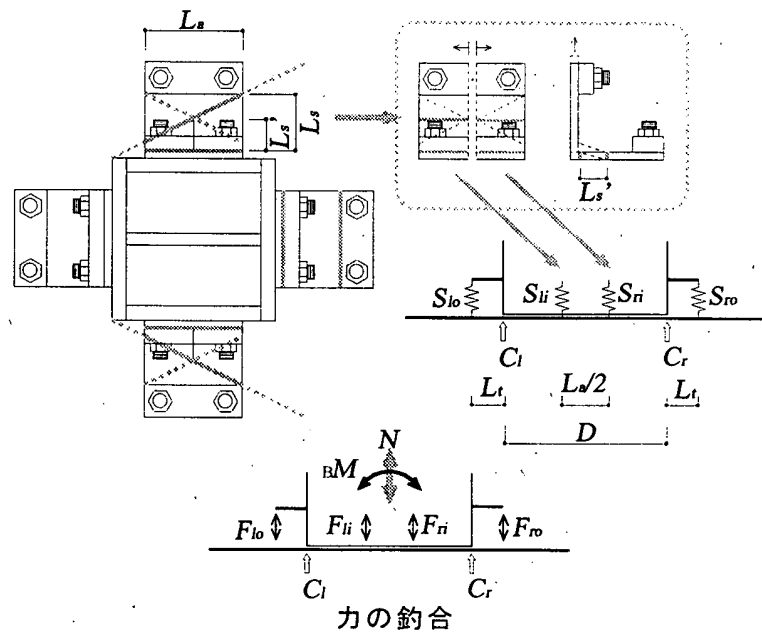

図-22 柱脚のモデル化
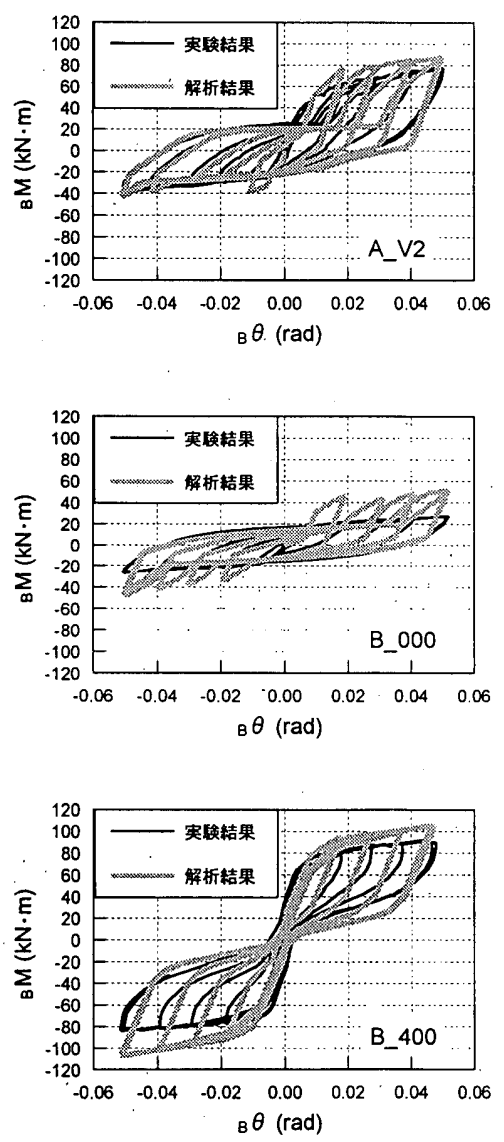


$$
\begin{array}{rl}
N= & F_{l o}+F_{l i}+F_{r i}+F_{r o}+C_{l}+C_{r} \\
{ }_{B} M= & \left\{F_{l o} \cdot\left(L_{t}+D / 2\right)+C_{l} \cdot D / 2+F_{l i} \cdot L_{a} / 2\right. \\
& \left.-F_{r i} \cdot L_{a} / 2-C_{r} \cdot D / 2-F_{r o} \cdot\left(L_{t}+D / 2\right)\right\} \cdot \cos _{B} \theta \\
\beth こ て ゙ 、 & D: \text { 柱成 } \\
& L_{a}: \text { アングルの幅 } \\
& { }_{B} \theta \text { :柱脚の回転角 }
\end{array}
$$

軸力および曲げモーメントの釣り合いと、変形の釣り合い条件から、 各バネの状態そして反力の分布が決まる。なお、せん断力Qは、圧 縮軸力による摩擦抵抗と側面のアングルによって柱から基礎に伝達 されることから、バネと圧縮反力でモデル化した柱脚の力学モデル には反映しなかった。

各試験体の荷重-変形関係の解析結果を実験結果と比較し、図-23 に示す。解析結果は実験結果と概ね良好に対応しており、図-22に 示すモデルにより、軸力と曲げモーメントを受ける柱脚の履歴挙動 が予測できることがわかった。

\section{5. 結論}

本研究では、地震時に塑性変形する箘所をアングルを用いた接合 金物に集約し、損傷後は変形箇所を交換することで継続使用する、 変形追従能力と補修性に優れた柱脚を提案した。この柱脚では、基 礎構造に埋め込まれ補修が困難なアンカーボルトを軸降伏させない ようにするだけでなく、ボルト位置でアングルを曲げ降伏させない ことが必要であることから、アングルの接合方法として、アンカー ボルト位置に板厚の厚い座板を設け曲げモーメントに抵抗させる夕 イプ(座板型)と、アンカーボルト位置に作用する曲げモーメントを 低減するため近傍に切り欠きを設けるタイプ(切欠型)の 2 つの方法 を採用した。アングルの履歴挙動に着目した要素レベルの実験なら びに部材レベルでの繰り返し載荷実験を行い、以下の結論を得た。

1)軸力と繰り返し曲げを受ける柱脚の履歷挙動は、変形要素である アングルの弹塑性挙動に基づいたものとなることから、柱脚に組み 込まれた状態を想定したアシグルの片振幅繰り返し載荷実験を行っ た。L-150x150x12 を使用した要素試験体は、座板型と切欠型のい ずれについても、柱の成が $250 \mathrm{~mm}$ であれば柱脚部の回転角で $1 / 10$ 、 $500 \mathrm{~mm}$ であれば 1/20 に相当する振幅まで安定した履歴挙動を示し ただけでなく、載荷終了に至るまで、アングルへの亀裂の発生およ びボルトの塑性変形は観察されなかった。本研究で提案した方法で 接合されたアングルは、露出型柱脚の接合金物としでは分な変形 領域に至るまで、安定した履歴举動を示す。

2)鉛直力を受けるアングル要素の履歴挙動について、主要変形要素 となる横材を、座板型では両端固定、切欠型では一端固定一端ピン の梁材、主として軸力を伝達する縌材を、両端ピンの剛体とした簡 単な力学モデルで表した。このカ学モデルに、バウシンガー効果を 考慮した履歴モデルを適用することで、繰り返し荷重を受けるアン グルの履歴挙動は、バウシンガー効果による剛性低下を含め予測で きる。
3)柱に作用する軸力と柱脚の接合金物であるアングルの接合方式を パラメーターとした柱脚の部材実験においては、全ての試験体が柱 脚の回転角で $1 / 20$ の大変形領域に至るまで安定した履歷挙動を示 した。柱脚部における変形は接合金物であるアングルの変形に集約 され、載荷終了に至るまでアングルへの亀裂の発生およびボルトの 塑性変形は観察されなかった。部材実験から、アングルを接合金物 として用いた露出型柱脚の変形追従能力の高さが検証できた。 4)柱脚の部材実験においては、全ての試験体でアングルを接合する 高力ボルトが損傷を受けなかったことから、載荷終了後のアングル の取り替えは支障無く行えた。本柱脚の特徴である補修性について も、実験的に検証できた。 5)アングルの浮き上がり挙動を表す力学モデルを、柱脚の力学モデ ルに適用することで、軸力と曲げを受ける柱脚の履歴挙動が概ね予 測できる。

\section{謝辞}

本研究は旭硝子財団平成 13 年度自然科学系研究助成(研究代表者 :山田 哲)の助成を受けた。ここに記して謝意を表す。

\section{参考文献}

1)山田 哲, 秋山 宏, 賁許美和: スリップ型の復元力特性を有寸る柱脚の弹 塑性挙動が鋼構造多層骨組の終局耐震性能に及ぼす影響, 日本建築学会構造 系論文集, 第 502 号, pp.141-147, 1997.12

2)小川博之, 貞許美和, 山田 哲, 秋山 宏: 施工性に優れた改良型露出型柱脚 の実験的研究 (その1.実験計画) (その2.実験結果), 日本建築学会学術講演梗 概集 構造而, pp.521-524, 1998.9

3)市川 俊, 荒木孝博, 増田浩志, 田中淳夫, 元田 徹, アンカーボルト先行降 伏型露出柱脚に関する研究-その 1 実験計画·結果- -その 2 考察一, 日本建 築学会学術講演梗概集 構造而, pp.617-620, 1999.9

4)是此田涉, 吉住孝志, 土井紀佳, 野田喜弘, 西小野芳壮, 暒山博光: ベースプレ 一ト降伏先行型鉄骨露出柱脚の弾塑性変形性状に関する研究 (その1)奏験 計画および実験結果 (その 2)履歴則と 1 方向復元力特性のモデル化, 日本建 築学会学術䛾演梗概集 構造III, pp.967-970, 2001.9

5)和田 章, 岩田 衛, 清水敬三, 安部重孝, 川合廣樹: 建築物の損傷制御設計, 丸善, 1998.

6)谷川充丈, 山田 哲, 和田 章: 弦材に忘力制限機構をもつトラス柱の提案 その 1 鋼管継ぎ手の実験，日本建築学会学沅講演梗概集 構造 III， pp.539-540, 2000.9

7)加藤 勉, 秋山 宏: 龬構造部材の耐力(その 4), 日本建築学会論文報告集, 第 151 号, pp.15-20, 1968.9

8)山田 哲, 秋山 宏, 桑村 仁: 局部座屈を伴う箱形断面鋼部材の劣化域を 含む終局挙動，日本建築学会構造系論文報告集，第 444 号, pp.135-144, 1993.2 9)秋山 宏, 高橋 誠: 鋼構造剛接骨組の耐震性に及ぼすバウシンガー効果の 影響, 日本建築学会構造系論文報告集, 第 418 号, pp.49-57, 1990.12 10)日本建築学会 : 鋼構造接合部設計指針, 2001.11

(2003年 4 月 8 日原稿受理, 2003 年 7 月 25 日採用決定) 